\title{
SPECIALTY RETAILERS IN CONSUMER ELECTRONICS TECHNO(LOGY) MARKETS AS A BUSINESS MODEL
}

\author{
Uğur YOZGAT \\ Marmara University, Turkey \\ Recep Baki DENIZ \\ Kültür University, Turkey
}

\begin{abstract}
The term business model describes a broad range of informal and formal models that are used by enterprises to represent various aspects of business, such as operational processes, organizational structures, and financial forecasts. Although the term can be traced to the 1950s, it achieved mainstream usage only in the 1990s. Different business models can be found in different areas. Especially, it is important to investigate the new business models in developing sectors. One of these developing sectors is specialty retailing. The specialty retailers operate in different markets. One of them is consumer electronics. Consumer electronics is a term used to describe the category of electronic equipment intended for everyday use by people. Consumer electronics are most often used in entertainment, communications and office productivity. Some products classed as consumer electronics include personal computers, telephones, audio equipment, televisions, calculators, and playback and recording of video media such as VCRs, DVD players, MP3 players and digital clocks are considered to be consumer electronics categories. Technology markets (specialty retail shops in consumer electronics) are one of the fast growing markets in Turkey
\end{abstract}

The aim of this paper is to investigate the specialty retail stores in consumer electronics, named as 'Techno(logy) Markets' by themselves and many people in Turkey, compare their business models, design, major products and services, owned brand names, slogans etc. operating in Turkey. Additionally, they will be compared with world giants BestBuy and Circuit City.

Keywords: Business Model, Specialty Retailing, Technology Market

\section{INTRODUCTION}

The term business model describes a broad range of informal and formal models that are used by enterprises to represent various aspects of business, such as operational processes, organizational structures, and financial forecasts. Although the term can be traced to the $1950 \mathrm{~s}$, it achieved mainstream usage only in the 1990s. Many informal definitions of the term can be found in popular business literature, such as the following:

A business model is a conceptual tool that contains a big set of elements and their relationships and allows expressing the business logic of a specific firm. It is a description of the value a company offers to one or several segments of customers and of the architecture of the firm and its network of partners for creating, marketing, and delivering this value and relationship capital, to generate profitable and sustainable revenue streams (Osterwalder, Pigneur and Tucci, 2005).

More recently, researchers build definitions based on economic and organizational theories and show that the definitions are econometrically sound. Malone, et al. (2006) give the definitions of sixteen business models and examples of these models.

The growing body of literature using the term business model shows that there is a continuum between authors using the term to simply refer to the way a company does business

Many different conceptualizations of business models exist (Chesbrough and Rosenbloom 2000; Hamel 2000; Linder and Cantrell 2000; Afuah and Tucci 2003; Osterwalder 2004; Fetscherin \& Knolmayer 2005). They all have various degrees of resemblance 
or difference. The model proposed by Osterwalder (2004) synthesis the different conceptualizations into a single reference model based on the similarities of a large range of models. The author's conceptualization describes a business model as consisting of nine related business model building blocks. Thus, a business model describes a company's business:

- value propositions: The company's offers which bundle products and services into value for the customer. A value proposition creates utility for the customer.

- target customer segments: The customer segments a company wants to offer value to. This describes the groups of people with common characteristics for which the company creates value. The process of defining customer segments is referred to as market segmentation.

- distribution channels: The various means of the company to get in touch with its customers. This describes how a company goes to the market. It refers to the company's marketing and distribution strategy.

- customer relationships: The links a company establishes between itself and its different customer segments. The process of managing customer relationships is referred to as customer relationship management.

- value configurations: The configuration of activities and resources.

- core capabilities: The capabilities and competencies necessary to execute the company's business model.

- partner network: The network of cooperative agreements with other companies necessary to efficiently offer and commercialize value. This describes the company's range of business alliances.

- cost structure: The monetary consequences of the means employed in the business model.

- revenue model: The way a company makes money through a variety of revenue flows.

These 9 business model building blocks constitute a business model design template which allows companies to describe their business model.

Morris, Schindehutte \& Allen (2005) mentioned six key questions addressed by business model which form the components of a business model; How will the firm create value? For whom will the firm create value? What is the firms internal source of advantage? How will the firm position itself in the marketplace? How will the firm make money? What are the entrepreneur's time, scope, and size?

Hedman \& Kalling (2003) proposed a generic business model that includes customers, competitors, offering, activities and organization, resources, supply of factor and production inputs, and scope of the management.

The process of business model design is a part of business strategy. The implementation of a company's business model into organizational structures (e.g. organigrams, workflows, human resources) and systems (e.g. information technology architecture, production lines) is a part of company's business operations. It is important to understand that business modeling commonly refers to business process design at the operational level, whereas business models and business model design refer to defining the business logic of a company at the strategic level (http://www.businessmodeldesign.com/wiki/index.p $\mathrm{hp}$ /What_is_a_Business_Model).

In a highly interconnected world enabled by advances in information and communication technologies, entrepreneurs and managers should look beyond firm and industry boundaries in order to capture and exploit business opportunities through the design of valuecreating business models. In order to succeed, entrepreneurs need not only to strike a balance between the new and the old in the products and services they bring to market, they must also define the right mix of design themes of their business models (Zott).

Different business models can be found in different areas. Especially, it is important to investigate the new business models in developing sectors. One of these developing sectors is specialty retailing. It attracts a broader audience among the new generations of consumers with higher disposable incomes. All over the world, people are looking to counteract the uniformity of supermarkets and shopping malls with the organized chaos and vitality of the bazaar. Research on North American consumers indicates that shoppers are clear about the way they classify shopping centers. For example, they define specialty centers as places where they go for things they want but do not need, and they describe conventional centers as places they go for things they need. Specialty centers offer a range of merchandise and a quality of service not available in conventional stores. Also, they often marry a broad merchandising mix with a strong theme to help provide a cohesive marketing and sales image. Design probably is the most important tool for creating a specialty center's image and for communicating that theme to the public. All of the fundamental forces for the expansion specialty shopping centers exist, including: 1. growing incomes for those who work, and 2. a growing awareness of style and design. To be successful, shopping center owners must start to think 
like their retailing tenants (Milligan, 1987)

Each retailer must determine his target clientele based on his catchments area, his competition, and the positioning of his outlet, and then define the merchandising strategy that will be reflected in the shop layout, the retail mix, the presentation and the product/service policy consistent with the chosen positioning.

Top 100 specialty retailers in USA saw 9.2 percent growth from 2003 to 2004 . These 100 specialty retailers have obviously succeeded in this area and are model companies that have demonstrated best practices in this industry (Vargas, 2004). Retail sales increased 6.1 percent in 2005 (http://www.nrf.com/content/ default.asp?folder $=$ press $/$ release $2006 \&$ file $=$ sales 06 . $\mathrm{htm}$ ) and 6.3 percent in 2006. NRF Forecasts $4.8 \%$ growth for 2007 retail sales (http:// w w w. n r f c o m/ content/pres s / release2007/forecast2007.htm).

\section{SPECIALTY RETAILERS IN CONSUMER ELECTRONICS}

The specialty retailers operate in different markets. One of them is consumer electronics. Consumer electronics is a term used to describe the category of electronic equipment intended for everyday use by people. Consumer electronics are most often used in entertainment, communications and office productivity. Some products classed as consumer electronics include personal computers, telephones, audio equipment, televisions, calculators, and playback and recording of video media such as VCRs, DVD players, MP3 players and digital clocks are considered to be consumer electronics categories. Popular brands of consumer electronics include a wide range of American and Japanese based companies including Apple, Sony, Toshiba, Panasonic, JVC and others.

Consumer electronics are manufactured throughout the world, although there is a particularly high concentration of manufacturing activity in the Far East, in particular China and Singapore, amongst other countries.

The most outstanding characteristic of all electronics products is the trend of low prices, which continue to drop. The reason of such price-drops is driven by gains in manufacturing efficiency and automation, as well as improvements in semiconductor design (http://travel.syl.com/consumerelectronicsevolvingf asterthan supplyand demand.html).
The two big players in the USA are Best Buy Co. Inc. and Circuit City; Best Buy Co., Inc., founded in 1966, sometimes called the "big blue box" because of the prominent design on Best Buy stores resembling a blue box., is a Fortune 100 company and the largest specialty retailer of consumer electronics in the United States and Canada, accounting for $17 \%$ of the market (Boyle, 2006). Circuit City, founded 1949, is a Fortune 200 company, and the third largest consumer electronics retailer in the United States with over $\$ 11$ billion USD in sales (http://www.answers.com/ topic/circuit-city). The second largest retailer in this market is Wallmart, which is not a pure player (also sells different products).

The Turkish electronic market size is calculated as 6 milliard Euro; 1.4 milliard Euro in electronics, 1.3 milliard Euro in telecommunication, 1.4 milliard Euro in computers, 1.8 milliard Euro in refrigerator, washer, dishwasher etc. Turkey is the seventh biggest market with 6 milliard Euro spending in Europe.

Technology markets (specialty retail shops in consumer electronics) are one of the fast growing markets in Turkey, and the market size is estimated 2 milliards Euro. They form $25 \%$ of the whole information and technology market. It's expected that this figure will seriously increase. The interest to the technology markets is increasing parallel to the changes of the Turkish consumer habits. Especially, as the mobile phones are considered as a status symbol by the low income consumers, this kind of consumers are willingly trying to change their old model phones with the new ones in the market. Moreover, long term sale conditions in technology markets show that the shopping are not limited with the medium and high level income consumers. Although Turkey with 80 Euro per person spending for electronics is below the European averages, the enthusiasm to consumption of electronics, especially computers and telecommunication devices, makes Turkish market attractive. (http://www.haber3. com/haber.php?haber_id=154796).

The world brand names such as Electronic Partner (EP), Virgin Megastore, RadioShack and last year Darty have already entered in the market, Dixons, Maplin, Costco and Media Markt, sub company of German Metro AG, are preparing (http://www.referans gazetesi.com/haber.aspx?HBR_KOD $=55075 \&$ KTG_KOD $=204 \&$ ForArsiv=1). Turkish players in this market are Teknosa, Vatan Computer, Bimex, Gold, Teknokolik, Teknolojix, Enplus and Teknorama (http://www.hurriyet.com.tr/ cuma/ 5208856.asp?gid=67). 


\section{RESEARCH}

\section{III.1. Aim}

The aim of this paper is to investigate the leading specialty retail stores in consumer electronics operating in Turkey, named as 'Techno(logy) Markets' by themselves and many people in Turkey, compare their business models, design, major products and services, owned brand names, slogans etc.

\section{III.2. Methodology}

A survey among 500 randomly chosen Doğuş, Kültür, Marmara and Yeditepe University students is conducted (Appendix.1).

Total 26 shops including Bimeks (Teknoport, Haramidere, Bayrampaşa ve İçerenköy Carrrefoursa, Acıbadem Nautilus), TeknoSa (Altunizade Capitol, Bakırköy Carousel, Bahcelievler Ömür, Haramidere, Bayrampaşa ve İçerenköy Carrefoursa, Kartal M1, Şişli Cevahir, Acıbadem Nautilus), Vatan (Topkapı, Bostanc1, Elmadağ), Gold (Altunizade, Bahçelievler, 4. Levent, Bostanc1, Paradise AVM Gürpınar), EP (Cevahir, Kartal M1, Beylikdüzü İstanbul Outlet Park), Teknolojix (Beykent d'silva) in Istanbul and websites (several times) including Best Buy and Circuit City are visited.

Their printed materials (flyers and newspaper ads) during the period 01.02-09.04-2007 are investigated.

Short semi-structured interviews are conducted with franchise stores vice president of Gold, managing partner of the consultancy company "Forte İletişim Danışmanlık" of Electronic Partner, advertising and promotion representatitive of Bimeks, marketing and corporate relations manager of Vatan Computer, representative of the consultancy company "Soylu \& Cengiz Danışmanlık" of Teknosa, vice president of Teknolojix and a questionnaire form was mailed (Appendix.2). All filled and re-mailed except Gold.

\section{III.3. Findings}

\section{III.3.1. General}

Techno-markets in Turkey are founded later than the American ones; Circuit City (1949), BestBuy (1966), Vatan (1983), Bimeks (1989), Gold (1990), Teknosa (2000), Teknolojix (2004), and ElectronicPartner (EP) (2005).

The headquarters of the technology-markets operating in Turkey are located in Istanbul excluding Teknolojix in Bursa and EP in Düsseldorf.

They used the buzzword "technology" in their slogans except Vatan and EP, where the slogans of the American ones have no relationship with technology; Teknosa (Technology for everyone), Bimeks (Focus on technology), Gold (Turkey's biggest technology store) Teknolojix (21.century's technology marketing), Vatan (Turkey's computer hyperstores), ElectronicPartner (Everthing plug in with the best price), BestBuy (Thousands of possibilities. Get yours), and Circuit City (Just what I needed).

Teknosa has more stores and operates in more cities than its competitors. Bimeks and Teknolojix have given franchise, and EP plan to give. The number of stores is given in table. 1 .

Table.1. Stores

\begin{tabular}{|lc|c|c|}
\hline & Company operated & Franchise & Total \\
\hline Teknos a & 164 & & 164 \\
\hline Vatan & 5 & & 5 \\
\hline Gold & 14 & 42 & 56 \\
\hline Bimeks & 22 & & 22 \\
\hline EP & 5 & & 5 \\
\hline Teknolojix & 11 & 34 & 45 \\
\hline
\end{tabular}

As of December 31, 2006, Circuit City's domestic segment operated 641 Superstores and 12 other locations in the U.S. Circuit City's international segment operated through 955 retail stores and dealer outlets in Canada. (http://investor.circuitcity.com/ faq.cfm?faqid=1).

Best Buy's subsidiaries include, and in, which together operate over 1150 stores in the, and (About Best Buy, Investor Relations,)

As of April 2007 the workforce deployed in Teknosa is approximately 2.500 , followed by Bimeks 550, Vatan 500, Teknolojix 230, EP Turkey 186, Circuit City 42.359 (February 28, 2006) and Best Buy approx. 120,000 .

Teknosa operates in 49 cities, Teknolojix in 24, Bimeks in 10 , Vatan and EP in 3 cities.

The store sizes of Vatan varies between $3500-18650 \mathrm{~m} 2$, EP between 1300-2500m2, Circuit City 1400-4000m2, Best Buy 1800-4200m2, Teknosa between 200$1000 \mathrm{~m} 2$, Bimeks average $300 \mathrm{~m} 2$, and Teknolojix total 
$9500 \mathrm{~m} 2$.

Bimeks, Gold, Teknosa, Vatan and EP have no private labels where Teknolojix (Trand, Boolex, and Tiemo), BestBuy (Insignia, Dynex, Init, Geek Squad, Rocketfish) and Circuit City (Anika, , ESA, , i-next, Liquid Video, Sector 7, Verge, Wasaki) have.

Teknosa represents a first in Turkey for number of stores and coverage of cities. Teknosa has shown a stable growth in a short time and became the most widespread technology retail in Turkey due to availability, fastness, quality and reliable service and product diversity. Teknosa adopted the philosophy "Technology for everyone". Offering the consumers any technological product they look for, Teknosa make available thousands of technological products including international trademarks for the consumers ().

Teknosa activated for the first time in Turkey the "TechnoConsultant" and "TechnoDictionary" functions on his website () with the intention to make aware its consumers about technology and aiming to be a technology consultant. Every three months product directories are published to inform its consumers about its technology products and to help their consumers during their purchasing decisions. Teknosa is also using inserts with a circulation over 2 million as an information source for their consumers to advice its promotions and to give information about its products' features and prices.

Vatan Computer as a pioneer in the technology retail marketing gives its consumers in its shops the opportunity to choose the products while benchmarking them through touching them in the same area. The company is conducting throughout the year lasting promotions on the benefit of consumers. Furthermore due its customer satisfaction policies believes Vatan Computer to get success with its qualified human resources and issues focused on customer satisfaction. Therefore the company provides education programs for their employees continuously. The main goal of these education programs is to increase the service quality and the customer satisfaction. Accordingly one of the most trusted matters of the company is qualified employees.

Teknolojix offers an excellent technical service before and after purchasing with its "extra support" corner and its "extra discounted products" corner instead of tricky best price offers. With its vision "Technology for a high quality life" it offers their consumers technological experiences. "Self Service" corners submit computers and notebooks for private use only, "Extra Service" in other words "VIP Customer Service" provides Teknolojix Cards. The company established "TEPA" "Teknology Retail Academy" to implement ARGE practices and to gain the qualified human resources needed for customer focused services. Teknolojix has also developed in-house the intelligent consumer centered dynamic retail management system TEXPOS.

Teknolojix is the first and only technology retailer certified by Quality Management System ISO:9001.

Bimeks with its young and experienced team offers its products while providing a real before sale counseling and an unique after sale technical service and aims always to reach $100 \%$ customer satisfaction. Due its service - product based structure, strong management team, to development and success concentrated personnel and qualitative service understanding has become one of the pioneers in the sector. Bimeks shops are in favorite shopping centers in order to offer the hot technology through easily accessible shops. In the recently opened Bimeks Teknoport Shop allows the consumers a wide testing possibility in a comfortable atmosphere. Consumers have a variety choice of services offered in Teknoport; customers with children can leave their children at the Child Caring Room (Children's Place) to have a convenient purchase opportunity. Further more at the "Teknobar" employees are in charge to answer any kind of technological question without having a selling intention. Another section is the PC Installation Section where consumers can create their own PC's with the parts they have bought from the Teknoport and the installation assistance is free of charge.

ElectronicPartner operates in 12 countries including Turkey (Germany, Holland, Belgium, Swiss, Austria, Italy, Poland, Hungary, Finland, Spain, Portugal) and has more than 6000 business partners. EP entered in the Turkish Market in 2005. They grouped the national/international products they sell in five core categories; electronics, white goods, small home appliances, IT/multimedia, cellular phones/ telecommunication, they also provide all accessories for the mentioned categories.

Circuit City is a company, and the third largest in the with over $\$ 11$ billion in sales (http://www.answers.com/topic/circuit-city). Circuit City's locations in Canada are operated by Canada Ltd which Circuit City acquired as of May 19, 2004. InterTAN runs (formerly) chain in (some of them 
now called La Source in Quebec) as well as, and GWiz.

In 2001, Circuit City introduced a new Superstore format which was much more in-line with the "'" store design than its previous layouts. Newer stores have a brighter, more open sales floor aimed to more easily allow customers to browse the merchandise. The format allows for the company to put all products, except those that are too large for a customer to carry themselves, on the sales floor. In August 2006, at a Las Vegas convention, the name for Circuit City's upgraded in-store and inhome services crew was unveiled as "SM." firedogSM provides in-home, in-store, and online PC Services, Home Theater Installations, and more. Circuit City has also developed, in partnership with, its first online virtualreality store based completely within the virtual world of. The store was opened in December, 2006, and houses $3 \mathrm{D}$ representations of actual product carried in stores. Online consumers can shop in the virtual store much like they would in a real store. The Second Life virtual store project was created as part of Circuit City's MultiChannel initiative to branch into other areas of retailing in addition to a standard store environment (www.twice.com/article/CA6400450.html?q=circuit+c ity).

Best Buy Co., Inc. is a company and the largest specialty of in the and, accounting for $17 \%$ of the market (money.cnn.com/magazines/fortune/ fortune_archive/2006/04/03/8373034/). Best Buy was named "Company of the Year" by magazine in (www.forbes.com/free_forbes/2004/0112/138.html), "Specialty Retailer of the Decade" by Discount Store News in (findarticles.com/p/articles/ mi_m0FNP/is_2_40/ai_70202157), ranked in the Top 10 of "America's Most Generous Corporations" by magazine (2005/11/11/charities-corporations-givingcx_lm_1114charity.html), and made Magazine's List of Most Admired Companies in (money.cnn.com/ magazines/fortune/mostadmired/full_list/).

Customer Centricity is the name of a business movement centered around catering to specific customer needs and behaviors. Best Buy's concept of customer centricity means configuring its stores to serve the needs of the particular customer segments that predominate in the area of that store. Some of the ways that the Best Buy company transforms its stores for a customer segment, is using different types of store signage, fixtures, lighting and even uniforms. One of the things the company has done for some segments is to create a personal shopping assistant, so that a customer can call and make an appointment for their shopping trip (). The company has created "lab stores" (separate from regular segmented stores) to test the area's acceptance to the theme and segment products and services.

Circuit City (1984) and BestBuy (1987) are listed on the where non of the Turkish companies on the Istanbul Stock Exchange.

\section{Social Responsibility Projects-Sponsorships}

With a view to contributing cultural and social life of the people and making future generations more conscious of technology, Teknosa supports many projects. Well aware of this social responsibility, Teknosa established Teknosa Academy to train the young people intending to make career in the field of technology retailing, and provide the ever-increasing sector with qualified workforce it requires. Training the retailing people of the future, Teknosa Academy aims at transferring innovations in the sector and improving competence of them. In the scope of the training given free of charge, the participants are also trained for management, professional and personal development. From the beginning of its establishment, Teknosa Academy has graduated over 1.500 persons, 80 persons a month in average (). Teknosa also started "Woman and Information Education" and İstanbul University Unique Pieces Library "Works Standing out to Time" project.

Teknosa supports national teams and Turkish Football Federation as the technology supplier of the national teams.

They installed the press room and business corner in many fairs to allow the press and businessmen access to the technology easier.

Vatan computer initiated computer literacy education in Ankara branch. They allocated $2500 \mathrm{~m} 2$ including 5 classes and 8 instructors. Their aim is to graduate 1.000 persons a month in average and total 12.000 persons a year. All given without any charge and no requirements asked.

Teknolojix is one of the sponsors of the TV-program "Binbir Gece".

Teknolojix plan to open new stores in every location having citizens more than 50.000 with the aim to bring the people in these areas together with the technology. They also give the entrepreneurs the chance to open their own shops through franchising using Teknolojix' ready and approved business model can be seen as an 
employment opportunity in these regions. They perceive it as a social responsibility.

Best Buy is the primary sponsor for team and their driver (www.nascar.com/2006/news/headlines/ cup/01/12/jgreen_bestbuy). The company started sponsoring in as an associate sponsor with their driver .

Best Buy cares about the communities in which they do business. They donate 1.5 percent of our pretax earnings to nonprofit organizations and supplement our financial commitment with an extensive, employeedriven volunteer network. The majority of their donations are administered by the Best Buy Children's Foundation. The Foundation is devoted to making learning interactive and fun by supporting innovative, high-tech programs that engage and educate elementary and secondary students. Their commitment to communities doesn't end with philanthropy, though. Over the past three years, Best Buy held events that have collected more than 1.2 million pounds of electronics for recycling. Yet the most valuable contributors to Best Buy communities are their employees. Their volunteerism and United Way donations touch communities directly, and their hard work brings our Company great success (www.bestbuy.com).

Circuit City Stores Inc. contributes to its communities in a number of ways through its Heart of the City initiative. Launched on May 7, 2006, this program is designed to harness the power of its Associates to take care of our communities and respond to emergencies through financial support and volunteerism. Heart of the City primarily supports three philanthropic programs:

United Way: Circuit City continues its longstanding support of this important agency that supports many vital community charities.

Boys \& Girls Clubs of America's Image Makers: Since 2000, Circuit City Foundation has partnered with Boys \& Girls Clubs of America to sponsor Image Makers, a national youth photography program. Through an annual donation of $\$ 1$ million, the program offers a photography curriculum, resource guides, volunteer programs, local, regional and national judging and scholarships. Image Makers supports the mission of more than 3,100 Boys \& Girls Clubs across the country. This collaboration provides an opportunity for Boys $\&$ Girls Clubs and Circuit City Stores nationwide to form a unique partnership that will benefit at-risk youth while giving Associates the opportunity to participate in the charitable work the company supports.

Associate Relief Fund: Inspired by Associate response to the Gulf Coast hurricanes of 2006, Circuit City has created this fund to enable Circuit City Associates to help each other in times of need.

The Heart of the City initiatives complement the work that the Circuit City Foundation has done since its establishment in 1962. Since that time, the Foundation has donated nearly $\$ 40$ million to support charitable causes including educational, arts and cultural organizations. The foundation administers a matching gifts program to boost the giving power of Associates.

In addition to supporting national programs, Circuit City Associates actively support local initiatives in the company's hometown, Richmond, Virginia. These programs include "Warm Wishes for Every Boy and Girl" for Boys \& Girls Clubs members, Boys \& Girls Clubs holiday parties, American Red Cross blood drives and Central Virginia Food Bank food drives (http://investor.circuitcity.com/community.cfm).

\section{III.3.2. Survey}

A questionnaire is given to 500 randomly chosen students from Doğuş, Kültür, Marmara and Yeditepe Universities. Of the $452(90.4 \%)$ questionnaires received $418(83.6 \%)$ were suitable to analyze.

The questionnaire consists of two demographic and eight open-ended questions (Appendix 1).

\section{Demographics}

On average, $395(94,50 \%)$ respondents were 22,27 years old (23 students did not answered) and 167 $(41,54 \%)$ of 402 respondents are female (16 students did not answered).

\section{Brand awareness}

The brand awareness of the technology markets are founded as follow; Teknosa $(\mathbf{9 7 . 8 5 \% )}$, Vatan (67.94\%), Gold (62.44\%), Bimeks (40.67\%), EP(9.81\%), and Teknolojix (1.91\%) (Table.2).

Teknosa is remembered by $\mathbf{7 5 . 6 0 \%}$ of the students as the first brand, followed by Gold $(10.77 \%)$, Vatan (7.89\%), Bimeks (4.31\%) and EP (0.96\%) (Table.2).

\section{Visits}

The mostly visited shop is Teknosa (89.71\%), followed by Gold (47.37\%), Vatan (46.65\%), Bimeks $(21.77 \%)$, EP (7.98\%), and Teknolojix (1.91\%) (Table.2). 
Table.2. Technology Markets

\begin{tabular}{|l|c|l|r|r|r|l|c|}
\hline \multicolumn{2}{|l|}{ Brand Awareness (\%) } & $\begin{array}{c}\text { Remembrance as First } \\
\text { Brand (\%) }\end{array}$ & \multicolumn{2}{c|}{ Visit Rate (\%) } & \multicolumn{2}{c|}{ Buying Rate (\%) } \\
\hline Tek n o s a & 97.85 & Teknosa & 75.60 & Tekn o s a & 89.71 & Tek n o s a & 58.61 \\
\hline Vatan & 67.94 & Vatan & 10.77 & Vatan & 47.37 & Vatan & 27.75 \\
\hline Gold & 62.44 & Gold & 7.69 & Gold & 46.65 & Gold & 26.56 \\
\hline Bimeks & 40.67 & Bimeks & 4.31 & Bimeks & 21.77 & Bimeks & 9.57 \\
\hline EP & 9.81 & EP & 0.96 & EP & 7.98 & EP & 4.78 \\
\hline Teknolojix & 1.91 & & & Teknolojix & 1.91 & Teknolojix & 0.72 \\
\hline
\end{tabular}

\section{Purchasing}

$58,61 \%$ of the respondents have been bought something from Teknosa, $27.75 \%$ from Gold, $26.56 \%$ from Vatan, 9.57\% from Bimeks, 4.78\% from EP, and $0.72 \%$ from Teknolojix (Table.2).

By the examination of table.2, it can easily be seen that Teknosa is on the first place in all of the categories, the differences between Teknosa and its competitors are extremely high and especially in the category of remembrance as first brand the ratio is almost seven times higher than its following competitor.

\section{Buying/Purchasing criterion} The price is the most mentioned criterion $(65.79 \%)$ followed by the brand reliance and warranty $(42.34 \%)$, quality $(30.86 \%)$, and design (30.86\%) (Table.3).

Quality is mentioned as the first criterion by $26.32 \%$ of the respondents, price by $19.38 \%$ and brand reliance and warranty by $16.27 \%$.

\section{Table.3. Buying/Purchasing Criterion}

\begin{tabular}{|l|c|}
\hline & Percentage (\%) \\
\hline Price & 65.79 \\
\hline Brand reliance and warranty & 42.34 \\
\hline Quality & 40.43 \\
\hline Design & 30.86 \\
\hline After sales and technical support & 18.42 \\
\hline Compensation of the needs & 17.22 \\
\hline Payment conditions & 5.74 \\
\hline Customer approach & 4.78 \\
\hline Distance & 2.15 \\
\hline Product variety & 0.48 \\
\hline
\end{tabular}

Where the frequency of the price is on the first rank, the respondents mentioned quality approximately $7 \%$ more than price as the first criterion. There could be two reasons; where the respondents students are, payment will be made by their parents and this technology friendly youth are used to the technoproducts so that they can examine and compare quality.

\section{Products considered have to be in techno-markets}

$77.27 \%$ of the respondents believe that computers (PC and notebook) should take place in these shops, followed by computer parts $(41.63 \%)$ and phones/cellular phones (37.56\%) (Table.4).

\section{Table.4. Products to be in Techno-markets}

\begin{tabular}{|l|c|}
\hline Product Line & Percentage (\%) \\
\hline Computers (PC and notebook) & 77.27 \\
\hline Cellular phones & 37.56 \\
\hline Digital cameras and camcorders & 30.54 \\
\hline TVs & 24.40 \\
\hline $\begin{array}{l}\text { Other (computer parts, peripherals, } \\
\text { home systems etc.) }\end{array}$ & 18.99 \\
\hline
\end{tabular}

\section{Perceived similarities and differences}

The respondents perceive that all of these sell almost the same products, techno-products, are focused on costumer satisfaction try to increase the level through customer services during and after sales, differentiated payment and price politics.

The differences are mentioned as follows;

Teknosa is widely expanded almost all over Turkey, has more shops, being a Sabanc1 Holding company increases trust to them, their sales-team members are 
knowledgeable, concerned on customers, make more advertisement, and their prices are relative expensive.

Gold, Vatan and Bimeks are relative rich in the product mix, have more products, their prices are relative cheap.

Vatan has very special payment advantages especially to Finansbank credit card owners.

Bimeks apply some additional discounts and gifts, their sales-team members are also knowledgeable and know how to deal with customers.

The respondents were finally asked if they are able to find out in which techno-shop they are in if no names and logos exist. The students visited shops of two or more technology markets think that they can find it out, because the shop design at all, especially the design of the shelves and stands are different. Colors used in the Teknosa stores and storefronts (orange) are recognized by the respondents as an important difference.

\section{III.3.3. Websites}

The websites of the examined techno-markets Bimeks (www.bimeks.com.tr), Gold (www.gold.com.tr), Teknosa (www.teknosa.com.tr), Vatan (www.vatanbilgisayar.com), ElectronicPartner (www.ep-netshop.de), BestBuy (www.bestbuy.com) and CircuitCity (www.circuitcity.com) are visited several times aiming to determine the brands (width) of each product line and total items carried (length) in of the consumer electronics product mix containing mostly cited product lines by the respondents. The product line widths and depths are given in the Table. 5 where detailed information can be found in Appendix.3.

The values of cellular phones is not given by EP, BB and $\mathrm{CC}$ because of the plans (telecommunication operator + cellular phones) started in Germany and USA.
PC product lines vary between 5 and 12 brands and depth between 25 and 41 products where Bimeks carries more brands and offers more products.

Notebook product lines vary between 7 and 16 brands and depth between 44 and 174 products where Vatan carries more brands and Bimeks offers more products. Monitor product lines vary between 8 and 21 brands and depth between 41 and 132 products where Bimeks carries more brands and Vatan offers more products.

Cellular phone product lines vary between 7 and 12

brands and depth between 80 and 248 products where Bimeks carries more brands and Teknosa offers more products.

TV product lines vary between 6 and 22 brands and depth between 13 and 161 products where Circuit City carries more brands and EP offers more products.

Digital camera product lines vary between 7 and 17 brands and depth between 48 and 191 products where Bimeks carries more brands and Circuit City offers more products.

Camcorder product lines vary between 3 and 10 brands and depth between 16 and 71 products where Circuit City carries more brands and offers more products.

Product lines and depths of PCs' are similar in the Turkish companies and others where the Turkish companies carry more notebooks and monitors brands and offer more products, and less TVs, digital cameras and camcorders on average.

\section{III.3.3. Flyers, Inserts, and Weekly Ads}

The flyers and inserts of Bimeks, Gold, Teknolojix,

Table.5. Consumer Electronics (Website)

\begin{tabular}{|l|r|c|c|c|c|c|c|c|}
\hline & Bimeks & Gold & Teknolojix & TeknoSa & Vatan & EP-NetShop & BB & CC \\
\hline PC & $\mathbf{1 2 ( 4 1 )}$ & $5(25)$ & $6(54)$ & $5(30)$ & $8(37)$ & $5(29)$ & $8(42)$ & $7(40)$ \\
\hline Notebook & $12(\mathbf{1 7 4})$ & $11(65)$ & $13(105)$ & $8(104)$ & $\mathbf{1 6}(\mathbf{1 3 2})$ & $7(44)$ & $9(56)$ & $9(85)$ \\
\hline Monitor & $\mathbf{2 1}(95)$ & $8(43)$ & $16(107)$ & $15(59)$ & $11(\mathbf{1 0 2})$ & $10(47)$ & $11(41)$ & $15(83)$ \\
\hline Cellular Phone & $\mathbf{1 2}(236)$ & $8(80)$ & $10(224)$ & $10(\mathbf{2 4 8})$ & $7(92)$ & - & - & - \\
\hline TV & $13(153)$ & $6(13)$ & $7(46)$ & $15(119)$ & $8(64)$ & $18(\mathbf{1 6 1})$ & $18(141)$ & $\mathbf{2 2}(143)$ \\
\hline Digital Camera & $\mathbf{1 7}(129)$ & $8(55)$ & $7(48)$ & $11(98)$ & $10(69)$ & $10(95)$ & $11(101)$ & $14(\mathbf{1 9 1})$ \\
\hline Camcorder & $5(41)$ & $4(16)$ & $3(17)$ & $4(33)$ & $3(17)$ & $5(64)$ & $9(56)$ & $\mathbf{1 0}(\mathbf{7 5})$ \\
\hline
\end{tabular}


Teknosa and EP, weekly ads of CircuitCity (circuitcity.shoplocal.com) and BestBuy (bestbuy. shoplocal.com) are examined. The product line widths and depths are given in the Table. 6 where detailed information can be found in Appendix.4.

The values of cellular phones is not given by $\mathrm{BB}$ and $\mathrm{CC}$ because of the plans (telecommunication operator + cellular phones) started in USA.
Bimeks has more PC, Gold and Teknolojix more monitor, Teknosa more digital camera and camcorder, Vatan more notebook, monitor and cellular phone and Circuit City more TV brands displayed in flyers, inserts and weekly ads.

Teknolojix has more monitors, Teknosa more cellular phones, TVs, digital cameras and camcorders, Vatan more PCs and notebooks displayed in flyers, inserts and weekly ads.

Table.6. Consumer electronics (Flyers, inserts, weekly ads)*

\begin{tabular}{|l|c|c|c|c|c|c|cc|}
\hline & Bimeks & Gold & Teknolojix & TeknoSa & Vatan & EP & BB & CC \\
\hline PC & $\mathbf{7 ( 1 5 )}$ & $4(13)$ & $5(11)$ & $5(9)$ & $6(23)$ & $1(1)$ & $4(5)$ & $3(6)$ \\
\hline Notebook & $7(33)$ & $6(18)$ & $7(28)$ & $5(16)$ & $\mathbf{9 ( 4 6 )}$ & $3(3)$ & $4(6)$ & $6(8)$ \\
\hline Monitor & $5(8)$ & $\mathbf{6 ( 1 8 )}$ & $\mathbf{6 ( 2 3 )}$ & $2(5)$ & $\mathbf{6}(16)$ & $1(3)$ & $2(5)$ & $3(4)$ \\
\hline Cellular Phone & $5(7)$ & $4(10)$ & $6(21)$ & $5(27)$ & $\mathbf{8}(14)$ & $3(4)$ & - & - \\
\hline TV & $5(12)$ & $5(6)$ & $3(12)$ & $9(37)$ & $4(20)$ & $4(7)$ & $10(28)$ & $\mathbf{1 2}(36)$ \\
\hline Digital Camera & $5(11)$ & $3(7)$ & $6(12)$ & $\mathbf{1 0 ( 2 7 )}$ & $8(20)$ & $3(3)$ & $5(5)$ & $5(12)$ \\
\hline Camcorder & $1(1)$ & $1(3)$ & $3(8)$ & $\mathbf{4 ( 1 0 )}$ & $2(4)$ & $1(1)$ & $5(5)$ & $3(8)$ \\
\hline Total Pages & 32 & 24 & 48 & 48 & 32 & $8(x 2)$ & 24 & 24 \\
\hline Date & $06-19.04$ & 04.07 & 04.07 & $07-15.04$ & 01.04 .07 & $07-13.04$ & 22.04 & 22.04 \\
\hline
\end{tabular}

Product lines and depths of PCs, notebooks, monitors and digital cameras (except Gold) showed in the Turkish companies flyers and inserts are more than American ones, where TVs and camcorders are less except Teknosa (EP is discarded).

\section{Payment}

Companies operating in Turkey are also competing in payment methods. They offer zero interest installment payment plans for different credit cards and discounts for cash and money orders payments (Table.7).

Table.7. Payment

\begin{tabular}{|c|c|c|c|c|c|c|c|}
\hline & & Vatan & Gold & TeknoSa & Bimeks & Teknolojix & EP \\
\hline \multicolumn{8}{|c|}{ Credit Card } \\
\hline & Worldcard & 12 & 9 & 12 & 12 & 12 & 15 \\
\hline & HSBC Advantage & & & 6 & & & 7 \\
\hline & Axess & 12 & 12 & 12 & & & 3 \\
\hline & Bonus & 12 & $\begin{array}{c}12 \\
6+10 \% \text { Bonus }\end{array}$ & & & 6 & 3 \\
\hline & Shop\&Smiles & & & & & & \\
\hline & CardFinans & $\begin{array}{c}17 \\
-8 \%+9 \\
\end{array}$ & 12 & 6 & 12 & 12 & $\begin{array}{l}3 \\
3 \\
\end{array}$ \\
\hline & Vakıf & & 15 & & & & \\
\hline & Fortis & & 15 & & & & \\
\hline & Citibank & & 12 & & & & \\
\hline & Maximum & & & 6 & 10 & 12 & \\
\hline & İdeal & & & & & 18 & \\
\hline & Wonder & & & & & $12+2$ month postpone & \\
\hline \multicolumn{2}{|l|}{ Cash } & $-5 \%$ & & & & $-5 \%$ & \\
\hline \multicolumn{2}{|c|}{ Money order } & $-5 \%$ & & $-3 \%$ & & & \\
\hline
\end{tabular}


Payment condition is on the seventh rank in the buying/purchasing criterion list of the respondents. It can affect the decision of the consumer.

If the given is compared, it can be seen that Vatan has a special installment payment plan for CardFinans credit card holders, Teknolojix for Ideal and EP for Worldcard above the average.

\section{CONCLUSION}

The Turkish electronic market size is calculated as 6 milliard Euro; 1.4 milliard Euro in electronics, 1.3 milliard Euro in telecommunication, 1.4 milliard Euro in computers, 1.8 milliard Euro in refrigerator, washer, dishwasher etc. Turkey is the seventh biggest market with 6 milliards Euro spending in Europe.

Technology markets (specialty retail shops in consumer electronics) are one of the fast growing markets in Turkey, and the market size is estimated 2 milliards Euro. They form $25 \%$ of the whole information and technology market.

Due to the young generations' deep interest in the technology, the increase of the usage of computers and internet, the development of e-trade, the renewal of the most inquired technological product, it's expected that the market will grow more and more.

The arrival of new players into the market and striving of the existing players in order to strengthen their positions in the market are the most important driving factors for this growth. But only if out of the book sales can be prevented, scientific and suitable investments can be made, enough investments for human resources can be done, well organized shopping malls can be established and not only the technology retail but also the retail sector will expand.

Turkey is especially considerable expanding in information retail in recent years. Its young and technology addicted generation put the information retail to the first row and is open continuously to follow the innovations. The back to back opening of local chains and the interest of the international chains in Turkey proves this expansion.

When the business models of the techno-markets are compared there are similarities among them. They open new stores continually to increase the number of their potential consumers they reach as much as they can. They provide high knowledgeable sales team members in order to answer the consumer's information requests. The stores are established in bigger sizes to enable a high range of product choice, to include a café etc. where the consumers can rest in during their visit.

As the product lines and depths are the same the differentiation strategies such as sales at more places, sales of more products, at bigger stores, lowest price guarantee etc. are used. To increase the awareness of the consumers continuously ads on newspapers are given.

The major techno-markets carry on extreme broad and intensive promotion activities, likewise campaigns and sales promotions to increase their sales. The situation shows a very high competition in the market whereas low level profit margins are reported.

Some examples of the sales campaigns (promotions) are as follows;

- Bimeks and Gold give their customers, who made a purchase of 1000.- USD or over, domestic roundtrip flight tickets for free,

- Bimeks guarantees " the lowest price" for its products,

- All techno-markets grant 12 installment possibility for some credit cards, All techno-markets give some gifts for some special purchases.

If we look to the future plans and goals of the technology retailers;

Bimeks keeps going its investments from two sides, on the first side it expands while opening 300 square meter stores in the shopping malls like before and on the other hand it continues to open big stores called Teknoport. For big stores cities like İstanbul (Asian Part), Bursa, İzmir, Ankara are in the first place. It is estimated that the store number will reach up to 36 within 2008 and up to 50 within 2010.

Electronic Partner aims to be an address for the latest model of technology products on sale. Over and above will continue to advise the consumer properly of the services and pay attention for after sale services.

Teknolojix will continue to open stores through franchising beside its own shops; so it achieves a faster and wider expansion and decrease its first investment costs with cooperating with entrepreneurs in their own regions. Its target is to achieve 300 stores, 2.000 employees and 1 billion dollar turnover in 2010 . Another important issue for Teknolojix is to become an international brand. 
Vatan aims to be a company in service with its 20 stores and 3 billion USD turnover in 2010.

Teknosa goals to bring the newest products for more people while increasing the number of its stores in cities where he has already activities and now opening stores in cities where it never have been before. Every month it spreads to every where in Turkey as planned in order to achieve 200 stores in 2007. It aims to last its Pioneer role in the sector due to its stores and qualified personnel investments.

They aim also to grow in Romania and increase the number of stores from 2 to 10 in 2007, and start new investments in Bulgaria and Ukraine. Their goal is to be a regional mark.

\section{Appendix.1: Survey Questions}

1. Give the names of the technology markets you know:
a.
b.
c.
d.
e.
f.

2. If you ever visited any technology market write the names and locations.

3. If you ever bought anything from the technology markets write the names and products.

If you have visited more than one technology market

4. What are the common features of these technology markets?

5. What are the unique features of these technology markets?

6. Are you able to find out in which technology market you are if no name tags and logos exist? How?

7. Give the have to be products in the technology markets.

8. Give your buying/purchasing criterion of any technology product and align them according your preference.
a.
b.
c.
d.
e.
f.

\section{Appendix.2: Company Information Form}

\begin{tabular}{|l|l|}
\hline Foundation date & \\
\hline Headquarter & \\
\hline Mission & \\
\hline Vision & \\
\hline Employees & \\
\hline Slogan(s) of your company & \\
\hline Number of stores & \\
\hline Location of the stores and sizes & \\
\hline Number of items carried & \\
\hline Franchise & \\
\hline Market share & \\
\hline Stock exchange & \\
\hline Private Labels & \\
\hline Sponsorships & \\
\hline Social responsibility projects & \\
\hline Define your company & \\
\hline Give the main differences of your company & \\
\hline What are your goals? & \\
\hline History of your company & \\
\hline Additionally to your company $\ldots$ & \\
\hline
\end{tabular}




\section{Appendix.3: Consumer electronics (website)*}

\begin{tabular}{|c|c|c|c|c|c|c|c|c|}
\hline & Vatan & Gold & TeknoSa & Bimeks & Teknolojix & EP-NetShop & BB & $\mathrm{CC}$ \\
\hline \multicolumn{9}{|l|}{ PC } \\
\hline Acer & 1 & & & 2 & & 11 & 5 & 3 \\
\hline Aidata & 8 & & & 3 & 15 & & & \\
\hline Asus & & & & 8 & 1 & & & \\
\hline Casper & & 3 & 5 & 9 & 9 & & & \\
\hline Crea & & 7 & 7 & 2 & 8 & & & \\
\hline Escort & 5 & & & 1 & & & & \\
\hline Exper & 5 & & 3 & 1 & & & & \\
\hline HP & 5 & 4 & 11 & 6 & 5 & 9 & 11 & 16 \\
\hline Packard Bell & 4 & & & 3 & & & & \\
\hline Pro 2000 & 6 & 2 & 4 & 4 & & & 1 & 3 \\
\hline Sony & & & & 1 & & & & \\
\hline Other... & Regal (3) & Pegasus (9) & & Byron(1) & Trand(16) & $\begin{array}{c}\text { Leo(4) } \\
\text { Fujitsu- } \\
\text { Siemens(4) } \\
\text { MaxData(1) }\end{array}$ & $\begin{array}{c}\text { Apple(7) } \\
\text { Compaq(2) } \\
\text { eMachines(6) } \\
\text { Gateway(6) } \\
\text { Veloc.Micro(4) }\end{array}$ & $\begin{array}{c}\text { Apple(5) } \\
\text { Compaq(4) } \\
\text { eMachines (4) } \\
\text { Gateway(5) }\end{array}$ \\
\hline Total & $8(37)$ & $5(25)$ & $5(30)$ & $12(41)$ & $6(54)$ & $5(29)$ & $8(42)$ & $7(40)$ \\
\hline \multicolumn{9}{|l|}{ Notebook } \\
\hline Acer & 14 & 8 & 4 & 19 & 6 & 13 & 5 & 8 \\
\hline Aidata & 2 & & & & 7 & & & \\
\hline Apple & & & 2 & & & & 6 & 5 \\
\hline Asus & 12 & 7 & & 11 & 18 & 10 & & \\
\hline Benq & 4 & & & & & 1 & & \\
\hline Casper & & & 2 & 3 & 5 & & & \\
\hline Compaq & 3 & & & & & & 4 & 4 \\
\hline Datron & 4 & & & & & & & \\
\hline Dell & 15 & 6 & 17 & 19 & 7 & & & \\
\hline Fujitsu-Siemens & 8 & 1 & & 6 & 8 & 5 & & \\
\hline $\mathrm{HP}$ & 12 & 15 & 46 & 27 & 21 & 8 & 9 & 20 \\
\hline \multicolumn{9}{|l|}{ IBM } \\
\hline LG & 10 & & & 11 & 4 & 5 & & \\
\hline Lenova & 6 & 1 & & 6 & & & & 5 \\
\hline MSI & 9 & 3 & & & 2 & & & \\
\hline Packard Bell & 10 & 7 & 6 & 6 & 4 & & & \\
\hline Sony & 2 & 6 & 3 & 27 & 10 & & 9 & 16 \\
\hline Toshiba & 20 & 10 & 24 & 38 & 11 & & 10 & 22 \\
\hline Vestel & 1 & 1 & & & & & & \\
\hline Other... & & & & Flybook(1) & $\operatorname{IBM}(2)$ & Maxdata(2) & $\begin{array}{c}\text { Durabook(1) } \\
\text { Gateway(11) } \\
\text { Samsung((1) } \\
\end{array}$ & $\begin{array}{c}\text { Gateway(4) } \\
\text { Everex(1) }\end{array}$ \\
\hline Total & $16(132)$ & $11(65)$ & $8(104)$ & $12(174)$ & $13(105)$ & $7(44)$ & $9(56)$ & $9(85)$ \\
\hline \multicolumn{9}{|l|}{ Monitor } \\
\hline Acer & 4 & 2 & & 5 & & 5 & 4 & 7 \\
\hline Aidata & & & & 2 & 2 & & & \\
\hline $\mathrm{AOC}$ & & & & & 2 & & & \\
\hline Apple & & & & 1 & & & 2 & 2 \\
\hline Asus & & 3 & & & 12 & 8 & & \\
\hline BenQ & 9 & 1 & 2 & 4 & 8 & 3 & & \\
\hline Casper & & & 3 & 1 & 3 & & & \\
\hline Crea & & 2 & 3 & 4 & 8 & & & \\
\hline Datron & 3 & & 2 & & & & & \\
\hline Dell & & 1 & 1 & 3 & 3 & & & \\
\hline Escort & & & 1 & 1 & & & & \\
\hline HP & & & 1 & 4 & 5 & 3 & 6 & 9 \\
\hline Hyundai & 4 & & 2 & 6 & & & & \\
\hline Inca & 2 & & & 2 & 1 & & & \\
\hline LG & 20 & 5 & 8 & 11 & 17 & 6 & 6 & 6 \\
\hline NEC & 2 & & & 2 & & & 1 & 13 \\
\hline Neuvo & 6 & & 2 & 3 & & & & \\
\hline Philips & 22 & 12 & 17 & 16 & 32 & 9 & & \\
\hline Samsung & 27 & 17 & 11 & 17 & 1 & 3 & 3 & 9 \\
\hline Viewsonic & 3 & & & 8 & 8 & & & 16 \\
\hline Other & & & $\begin{array}{c}\text { Medion(2) } \\
\text { Pro2000(1) } \\
\text { Sony(3) } \\
\text { PackardBell(1) }\end{array}$ & $\begin{array}{l}\text { Byron(1) } \\
\text { Exper(1) } \\
\text { GO(2) }\end{array}$ & $\begin{array}{c}\text { Genesis(1) } \\
\text { IBM(3) } \\
\text { Macintosh(1) } \\
\text { ITT(1) }\end{array}$ & 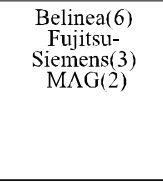 & $\begin{array}{c}\text { eMachines(3) } \\
\text { Envision(3) } \\
\text { Gateway(5) } \\
\text { Westinghouse(6) }\end{array}$ & $\begin{array}{c}\text { Compaq(2) } \\
\text { eMachines(3) } \\
\text { Envision(2) } \\
\text { Gateway(4) } \\
\text { HC(2) } \\
\text { Proview(4) } \\
\text { StarLogic(3) } \\
\text { Xerox(1) }\end{array}$ \\
\hline Total & $11(102)$ & $8(43)$ & $15(59)$ & $21(95)$ & $16(107)$ & $10(47)$ & $11(41)$ & $15(83)$ \\
\hline
\end{tabular}


Appendix.3: Consumer electronics (website)* continued

\begin{tabular}{|c|c|c|c|c|c|c|c|c|}
\hline & Vatan & Gold & TeknoSa & Bimeks & Teknolojix & EP-NetShop & BB & $\mathrm{CC}$ \\
\hline \multicolumn{9}{|l|}{ Cellular phone } \\
\hline \multicolumn{9}{|l|}{ Asus } \\
\hline General Mobile & & 1 & 1 & 1 & 1 & & & \\
\hline Gigabyte & & 1 & & 1 & & & & \\
\hline LG & 12 & 2 & 16 & 9 & 14 & & & \\
\hline Motorola & 9 & 2 & 21 & 20 & 11 & & & \\
\hline Nokia & 20 & 50 & 91 & 105 & 83 & & & \\
\hline Philips & & & 24 & 6 & 19 & & & \\
\hline Raks & & & & 1 & 3 & & & \\
\hline Samsung & 19 & 12 & 38 & 54 & 53 & & & \\
\hline Siemens & 7 & 1 & 23 & 2 & 11 & & & \\
\hline Sony Ericsson & 20 & 11 & 29 & 26 & 28 & & & \\
\hline Toshiba & 5 & & 4 & 6 & 1 & & & \\
\hline Other... & & & Panasonic(1) & $\mathrm{Kg} 110(5)$ & & & & \\
\hline Total & $7(92)$ & $8(80)$ & $10(248)$ & $12(236)$ & $10(224)$ & & & \\
\hline \multicolumn{9}{|l|}{$\mathrm{TV}$} \\
\hline Crea & & & 4 & 4 & 1 & & & \\
\hline Hitachi & & & 1 & 1 & & & 2 & 4 \\
\hline JVC & & & 3 & & & 10 & 2 & \\
\hline LG & 13 & 3 & 17 & 20 & 9 & 9 & 9 & 8 \\
\hline Panasonic & 7 & 2 & 7 & 15 & 4 & 15 & 6 & 10 \\
\hline Philips & 7 & & 19 & 37 & 13 & 24 & 5 & 7 \\
\hline Pioneer & 1 & 3 & 2 & 6 & 4 & & 3 & \\
\hline Samsung & & & 18 & 17 & & 16 & 35 & 26 \\
\hline Sharp & & & 4 & & & 8 & 13 & 10 \\
\hline Sony & 11 & 1 & 20 & 20 & 13 & 7 & 16 & 23 \\
\hline Toshiba & 14 & 2 & 10 & 21 & & 9 & 21 & 12 \\
\hline Other & $\begin{array}{c}\text { Aidata(1) } \\
\text { Siemens }(10)\end{array}$ & Diboss(2) & $\begin{array}{c}\text { Navitech(5) } \\
\text { Thomson(4) } \\
\text { OEM(1) } \\
\text { SchaubLorenz(4) }\end{array}$ & $\begin{array}{c}\text { Hyundai(1) } \\
\text { Sunny(7) } \\
\text { Verde(3) } \\
\text { Viewsonic(1) }\end{array}$ & Aidata(2) & $\begin{array}{c}\text { Akai(1) } \\
\text { Lenco(5) } \\
\text { Daewoo(16) } \\
\text { Grundig(23) } \\
\text { Humax(7) } \\
\text { ITT(1) } \\
\text { Funai(5) } \\
\text { Fujitsu- } \\
\text { Siemens(3) } \\
\text { TechniSat(2) } \\
\text { Batavia(1) }\end{array}$ & $\begin{array}{c}\text { Dynex(3) } \\
\text { HP(4) } \\
\text { Insignia(9) } \\
\text { Maxent(2) } \\
\text { Mitsubishi(2) } \\
\text { Optoma(2) } \\
\text { Sylvania(2) } \\
\text { Westinghouse(5) } \\
\\
\end{array}$ & $\begin{array}{c}\text { Advent(1) } \\
\text { Element(6) } \\
\text { HP(1) } \\
\text { Mitsubishi(5) } \\
\text { Polaroid(11) } \\
\text { PrimabyAlux(3) } \\
\text { RCA(1) } \\
\text { Spectra(1) } \\
\text { Sylvania(5) } \\
\text { Symphonic(3) } \\
\text { SyntaxOle.(2) } \\
\text { Viewsonic(1) } \\
\text { Vizio(2) } \\
\text { Zenith(1) }\end{array}$ \\
\hline Total & $8(64)$ & $6(13)$ & $15(119)$ & $13(153)$ & $7(46)$ & $18(161)$ & $18(141)$ & $22(143)$ \\
\hline \multicolumn{9}{|l|}{ Digital Camera } \\
\hline Canon & 20 & 17 & 14 & 24 & 34 & 25 & 16 & 30 \\
\hline Casio & 8 & & 7 & 7 & & & 13 & 14 \\
\hline FujiFilm & & 4 & 14 & & & 1 & 7 & 11 \\
\hline $\mathrm{HP}$ & 5 & 3 & 2 & 6 & 2 & & 3 & 11 \\
\hline Kodak & 4 & 6 & 4 & & & 1 & 8 & 10 \\
\hline Nikon & 8 & 13 & 8 & 10 & & 9 & 8 & 16 \\
\hline Olympus & 3 & & 7 & 12 & 1 & 22 & 12 & 26 \\
\hline Panasonic & 6 & 4 & 3 & 8 & & 8 & 8 & 18 \\
\hline Pentax & 5 & & & 6 & & 10 & 2 & 6 \\
\hline Samsung & 3 & 4 & 11 & 7 & 5 & 11 & 11 & 15 \\
\hline Sanyo & & & 9 & 6 & & & & 1 \\
\hline Sony & 7 & 4 & 19 & 17 & 4 & 7 & 12 & 27 \\
\hline Other... & & & & $\begin{array}{c}\text { Acer(2) } \\
\text { Creative(5) } \\
\text { Go(1) } \\
\text { Ogatech(5) } \\
\text { Orite(5) } \\
\text { Pretec(1) } \\
\text { Sunny(7) } \\
\end{array}$ & $\begin{array}{c}\text { Orite(1) } \\
\text { Practica(1) }\end{array}$ & Acer(1) & & $\begin{array}{c}\text { DXG(1) } \\
\text { Polaroid(5) }\end{array}$ \\
\hline Total & $10(69)$ & $8(55)$ & $11(98)$ & $17(129)$ & $7(48)$ & $10(95)$ & $11(101)$ & $14(191)$ \\
\hline \multicolumn{9}{|l|}{ Camcorder } \\
\hline Canon & 6 & 4 & 2 & 12 & 3 & 16 & 9 & 11 \\
\hline Hitachi & & & & 4 & & & 3 & 5 \\
\hline JVC & & & 5 & & & 10 & & 12 \\
\hline Panasonic & 7 & 5 & & 9 & & 13 & 10 & 13 \\
\hline Sanyo & & & 5 & & & & 4 & 1 \\
\hline Samsung & & 2 & & 3 & 2 & 6 & 2 & 4 \\
\hline Sony & 4 & 5 & 21 & 13 & 12 & 19 & 18 & 19 \\
\hline Other & & & & & & & $\begin{array}{c}\text { Aiptek(3) } \\
\text { DXG(4) } \\
\text { PureDigital(3) }\end{array}$ & $\begin{array}{l}\text { Aiptek(3) } \\
\text { DXG(5) } \\
\text { RCA(2) }\end{array}$ \\
\hline Total & $3(17)$ & 4 (16) & $4(33)$ & $5(41)$ & $3(17)$ & $5(64)$ & $9(56)$ & $10(75)$ \\
\hline
\end{tabular}


Appendix.4: Consumer electronics (flyers, inserts, weekly adds)

\begin{tabular}{|c|c|c|c|c|c|c|c|c|}
\hline & Vatan & Gold & TeknoSa & Bimeks & Teknolojix & EP & $\mathrm{BB}$ & $\mathrm{CC}$ \\
\hline \multicolumn{9}{|l|}{$\mathbf{P C}$} \\
\hline Acer & & & & 1 & & & 1 & \\
\hline Aidata & 4 & & & & 3 & & & \\
\hline Casper & & 4 & 2 & 3 & 3 & & & \\
\hline Compaq & & & & & & & & 2 \\
\hline Crea & & & 2 & 2 & 1 & 1 & & \\
\hline Escort & 4 & & & & & & & \\
\hline Exper & & & 1 & & & & & \\
\hline HP & 6 & 4 & 2 & 5 & 1 & & 1 & 3 \\
\hline Packard Bell & 4 & & & 2 & & & & \\
\hline Pro2000 & 4 & 3 & 2 & 1 & & & & \\
\hline Other... & Regal(1) & Pegasus(2) & & $\operatorname{Dell}(1)$ & Trend(3) & & $\begin{array}{c}\text { Gateway(2) } \\
\text { eMachines(1) }\end{array}$ & Gateway(1) \\
\hline Total & $6(23)$ & $4(13)$ & $5(9)$ & $7(15)$ & $5(11)$ & $1(1)$ & $4(5)$ & $3(6)$ \\
\hline \multicolumn{9}{|l|}{ Notebook } \\
\hline ACER & 6 & 1 & & 1 & 4 & 1 & & 1 \\
\hline Asus & 4 & & & & 4 & 1 & & \\
\hline Dell & 8 & 3 & 2 & 6 & 4 & & & \\
\hline Fuji.-Siemens & 4 & & & 2 & & & & \\
\hline HP & 8 & 6 & 7 & 12 & 6 & 1 & 1 & 3 \\
\hline MSI & & 3 & & & & & & \\
\hline Packard Bell & 4 & & 3 & & & & & \\
\hline Toshiba & 8 & 4 & 3 & 7 & 6 & & 3 & 1 \\
\hline Vestel & 1 & 1 & & & & & & \\
\hline Other... & Datron(3) & & Compaq(1) & $\begin{array}{c}\text { Sony(3) } \\
\text { Lonovo(2) }\end{array}$ & $\begin{array}{l}\text { Aidata(2) } \\
\text { Casper(2) }\end{array}$ & & $\begin{array}{l}\text { Compaq(1) } \\
\text { Gateway(1) }\end{array}$ & $\begin{array}{c}\text { Compaq(1) } \\
\text { Sony(1) } \\
\text { Gateway(1) }\end{array}$ \\
\hline Total & $9(46)$ & $6(18)$ & $5(16)$ & $7(33)$ & $7(28)$ & $3(3)$ & $4(6)$ & $6(8)$ \\
\hline \multicolumn{9}{|l|}{ Monitor } \\
\hline Benq & & 1 & & & 4 & & & \\
\hline Datron & 2 & 2 & & & & & & \\
\hline LG & 2 & 3 & & 1 & 4 & & & \\
\hline Philips & 4 & 4 & 3 & 2 & 8 & & & \\
\hline Samsung & 4 & 6 & 2 & 1 & & & 2 & 2 \\
\hline Vicwsonic & & & & 3 & 4 & & & \\
\hline Other & $\begin{array}{l}\text { Neuvo(2) } \\
\text { Hyundai(2) }\end{array}$ & Belinia(2) & & Go(1) & $\begin{array}{l}\text { Asus(2) } \\
\text { Inca(1) }\end{array}$ & Crea(3) & Westingh.(3) & $\begin{array}{l}\text { Proview(1) } \\
\text { Gateway(1) }\end{array}$ \\
\hline Total & $6(16)$ & $6(18)$ & $2(5)$ & $5(8)$ & $6(23)$ & 1(3) & $2(5)$ & $3(4)$ \\
\hline \multicolumn{9}{|l|}{ Handyphone } \\
\hline General Mobile & & 1 & & 1 & 1 & & & \\
\hline LG & & 3 & 8 & 2 & 4 & & & \\
\hline Motorola & 1 & & & 1 & & & & \\
\hline Nokia & 2 & & & 2 & 4 & $\mathrm{x}$ & & \\
\hline Philips & & 3 & 7 & & & $\mathrm{x}$ & & \\
\hline Samsung & 3 & 3 & 8 & 1 & 4 & $\mathrm{x}$ & & \\
\hline Sony Ericsson & 4 & & 3 & & 4 & & & \\
\hline Other... & $\begin{array}{c}\text { Asus(1) } \\
\text { Qtek(1) } \\
\text { HP(1) } \\
\text { Toshiba(1) }\end{array}$ & & Qtek(1) & & $\begin{array}{c}\text { Benq- } \\
\text { Siemens(4) }\end{array}$ & & & \\
\hline Total & $8(14)$ & $4(10)$ & $5(27)$ & $5(7)$ & $6(21)$ & $3(4)$ & & \\
\hline \multicolumn{9}{|l|}{ TV } \\
\hline LG & & 2 & 7 & & 5 & & 1 & 2 \\
\hline Panasonic & 3 & 1 & 1 & 2 & & & & 2 \\
\hline Philips & 4 & 1 & 6 & 1 & 4 & 1 & & \\
\hline Samsung & & & 9 & 4 & & 1 & 6 & 2 \\
\hline Sharp & & & 1 & & & & 4 & 2 \\
\hline Sony & 8 & 1 & 4 & 1 & 3 & & 7 & 12 \\
\hline Toshiba & 5 & & 4 & 4 & & 4 & 1 & 8 \\
\hline Total & & Crea (1) & $\begin{array}{c}\text { Pioneer(2) } \\
\text { JVC (3) }\end{array}$ & & & $\begin{array}{c}\text { Saba(1) } \\
\text { Profilo(1) }\end{array}$ & $\begin{array}{c}\text { Pioneer(2) } \\
\text { JVC(1) } \\
\text { HP(2) } \\
\text { Insignia(1) } \\
\text { Dynex(3) }\end{array}$ & $\begin{array}{c}\text { Element(1) } \\
\text { Hitachi(3) } \\
\text { Olevia(1) } \\
\text { Symphonic(1) } \\
\text { Vizio(1) } \\
\text { Zenith(1) }\end{array}$ \\
\hline Total & $4(20)$ & $5(6)$ & $9(37)$ & $5(12)$ & $3(12)$ & $4(7)$ & $10(28)$ & $12(36)$ \\
\hline \multicolumn{9}{|l|}{ Digital Kamera } \\
\hline Canon & 6 & & 4 & 5 & 5 & & 1 & 3 \\
\hline Casio & 2 & & & & & & 1 & \\
\hline Fujifilm & & & 3 & & & & & \\
\hline HP & & & 1 & & 1 & & & 1 \\
\hline Kodak & 3 & 3 & 1 & & & 1 & 1 & \\
\hline Nikon & 3 & & 4 & & & 1 & 1 & 3 \\
\hline Olmpus & 1 & & 3 & 2 & 1 & & & 2 \\
\hline Panasonic & 2 & & 1 & 2 & & & & \\
\hline Samsung & 1 & 1 & 5 & 1 & 1 & 1 & & \\
\hline Sony & 2 & 3 & 3 & & 2 & & 1 & 3 \\
\hline Other... & & & Sanyo(2) & Orite(1) & $\operatorname{Practica}(2)$ & & & \\
\hline Total & $8(20)$ & $3(7)$ & $10(27)$ & $5(11)$ & $6(12)$ & $3(3)$ & $5(5)$ & $5(12)$ \\
\hline Camcorder & & & & & & & & \\
\hline Canon & 2 & & 2 & 1 & 4 & & 1 & \\
\hline JVC & & & 2 & & & & 1 & 3 \\
\hline Samsung & & & & & 2 & & & \\
\hline Sony & 2 & 3 & 5 & & 2 & 1 & 1 & 4 \\
\hline Other... & & & Sanyo(1) & & & & $\begin{array}{c}\text { Hitachi(1) } \\
\text { Panasonic(1) }\end{array}$ & Panasonic(1) \\
\hline Total2(4) & 1(3) & $4(10)$ & 1(1) & $3(8)$ & $1(1)$ & $5(5)$ & $3(8)$ & \\
\hline Total Pages & 32 & 24 & 48 & 32 & 48 & $8(x 2)$ & 24 & 24 \\
\hline Date & 01.04 .07 & 04.07 & $07-15.04$ & $06-19.04$ & 04.07 & $07-13.04$ & 22.04 & 22.0 \\
\hline
\end{tabular}




\section{REFERENCES}

About Teknosa. Teknosa.

(http://www.sabanci.com/en/grup_baskanliklari_sir ket.asp?ID=114). [April 28, 2007].

Afuah, Allan and Christopher L. Tucci. (2003). Internet Business Models and Strategies: Text and Cases. 2nd Edition. New York: McGraw-Hill Companies, Inc.

America's Most Admired Companies 2006. CNN. (http://money.cnn.com/magazines/fortune/ mostadmired/full_list/). [April 28, 2007].

Barry Berman \& Joel R. Evans. Retail Management, A Strategic Approach, 10 th Ed. Pearson Prentice Hall, 2007

BestBuy. (http://www.bestbuy.com). [April 27, 2007].

Best Buy on board with Green's No. 66. NASCAR. January 12, 2006. (http://www.nascar.com/2006/news/ headlines/cup/01/12/jgreen_bestbuy). [April 28, 2007].

Bimeks. (www.bimeks.com.tr). [April 27, 2007].

Boyle, Matthew. Best Buy's Giant Gamble. March 29, 2006. (http://money.cnn.com/magazines/fortune/ fortune_archive/2006/04/03/8373034/). [February 8, 2007].

Chesbrough, Henry and Rosenbloom, Richard S. (2002). The Role of the Business Model in Capturing Value From Innovation: Evidence From Xerox Corporation's Technology Spin-off Companies. Industrial and Corporate Change, Vol.11, No.3, pp.529555.

Circuit City. (http://www.circuitcity.com/ccd/home.do). [February 10, 2007].

Consumer electronics -- Evolving faster Than Supply and Demand. December 14, 2005.

(http://travel.syl.com/consumerelectronicsevolvingf asterthansupplyanddemand.html).

[February 3, 2007].

Darty. (http://www.darty.com.tr). [February 9, 2007].

Demir Sabanci'dan TeknoSA'ya rakip. September 5, 2006. (http://www.haber3.com/haber.php?haberid= 154796). [February 8, 2007].

DSN honors Best Buy with Specialty Retailer award.
Discount Store News. January 22, 2001.

(http://findarticles.com/p/articles/mi_m0FNP/is_2 40/ai_70202157). [April 28, 2007].

Electronic Partner.

(http://www.electronicpartner.com.tr). [February 8 , 2007].

Enplus. (http://www.enplus.com.tr/). [February 9 , 2007].

Fetscherin, Marc \& Knolmayer, Gerhard. (2004). Business Models for Content Delivery: An Empirical Analysis of the Newspaper and Magazine Industry. The International Journal on Media Management, Vol. 6, No. 1\&2, pp.4-11.

Gold Bilgisayar. (www.gold.com.tr/). [April 27, 2007].

Hamel, Gary. (2000). Devrimin Başına Geçin. Nurettin Elhüseyni (çev.). İstanbul: MESS Yayınları, Yayın No.341.

Hedman, Jonas \& Kalling, Thomas. (2003). The Business Model Concept: Theoretical Underpinnings and Empirical Illustrations. European Journal of Information Systems, Vol.12, Issue.1, pp.49-59.

Hürriyet - En iyi 10 teknoloji market. October 6, 2006. (http://www.hurriyet.com.tr/cuma/ 5208856.asp?gid=67). [February 10, 2007].

İngiliz teknoloji marketini getirdi, 20 mağaza açacak. December 14, 2006. (http://www.referansgazetesi.com/ haber.aspx?HBR_KOD $=55075 \&$ KTG KOD $=204 \&$ ForArsiv=1). [February 10, 2007].

Linder, Jane C. and Cantrell, Susan. (2000). Changing Business Models: Surveying the Landscape. May 25. (http://www.accenture.com/Global/Research_and_I nsights/Institute_For_High_Performance_Business/ By_Subject /Strategy/BeInternet.htm). [February 10, 2007].

Sullivan, Malcolm \& Adcock, Dennis. Retail Marketing. Thomson, 2002.

Malone, Thomas W., Weill, Peter, Lai, Richard K., D'Urso, Victoria T., Herman, George, Apel, Thomas G. and Woerner, Stephanie. (2006). Do Some Business Models Perform Better than Others? MIT Sloan Research Paper No. 4615-06. May.

Milligan, John, (1987). Specialty Shopping: Its 
Effective Promotion. Retail \& Distribution Management. Sep/Oct. Vol. 15, Iss. 5, pp.66-67 (http://proquest.umi.com/pqdweb?index $=4 \&$ did $=$ $1290141 \&$ SrchMode $=1 \&$ sid $=5 \& \mathrm{Fmt}=2 \& \mathrm{VInst}=\mathrm{PR}$ OD\&VType $=$ PQD $\& R Q T=309 \& V$ Name $=$ PQD $\& T S$ $=1171271264 \&$ clientId=43845). [February 10, 2007].

More CE Purchase Proceeded by Online Research, June 11, 2006.

(http://www.twice.com/article/CA6388569.html).

[February 10, 2007].

Morris, Michael; Schindehutte, Minet \& Allen, Jeffrey. (2005). The Entrepreneur's Business Model: Toward A Unified Perspective. Journal of Business Research, Vol. 58, Iss. 6, pp.726-735.

Moyer, Liz. The Most Charitable Companies. Forbes. November 14, 2005.

(http://www.forbes.com/personalfinance/philanthro py/2005/11/11/charities-corporations-giving-cx_lm 1114charity.html). [April 28, 2007].

Osterwalder, Alexander; Pigneur, Yves \& Tucci, Christopher L. (2005). Clarifying Business Models: Origins, Present, and Future of the Concept. Communications of AIS. Vol.15, May, pp.1-25.

Satıș Kanallarında Taşlar Yerinden Oynuyor, November 2005. (http://www.bilisimdunyasi.net.tr/ yazi.asp?sayi=1\&yazi=204). [February 10, 2007].

Sweeping Changes in Consumer Electronics, November 16, 2006. (http://www.gfk.com/group/ press_information). [February 10, 2007].

Tatge, Mark. Fun \& Games. Forbes. January 12, 2004. http://www.forbes.com/free forbes/2004/0112/ 138.html). [April 28, 2007].

Teknokolik. (www.teknokolik.com.tr). [February 3, 2007].

Teknolojix. (http://www.teknolojix.com). [April 27, $2007]$.

Teknorama. (www.teknorama.com.tr). [February 3, 2007].

Teknosa. (www.teknosa.com.tr). [April 27, 2007].

Vargas, Melody. Top 100 Specialty Store Retailers. (http://retailindustry.about.com/od/sales_retailers/a/ 04_topspec_nrf.htm). [February 3, 2007].
Vatan Computer. (www.vatanbilgisayar.com). [April 27, 2007].

Zott, Christoph \& Richter, Gérard. Beyond the Big Idea. Business Model Design and the Performance Predictors in Entrepreneurial Firms.

(http://knowledge.insead.edu/abstract.cfm?ct=11786). [February 10, 2007].

Walmart. (http://www.walmart.com). [February 10, 2007].

What is a Business Model.

(http://www.businessmodeldesign.com/wiki/index.php/ What_is_a_Business_Model). [February 3, 2007].

Wolf, Alan. Circuit City Opening Virtual 3-D Store. (http://www.twice.com/article/CA6400450.html?q $=$ circuit + city $)$. [April 28, 2007].

(http://www.answers.com/topic/circuit-city). [April 27, 2007].

(http://www.ce.org). [February 10, 2007].

A ğalar, Hasan. Gold. Franchise stores vice president. [April 28, 2007]

Dikkaya, Semenç. Managing partner of the consultancy company "Forte İletişim Danışmanlık" of Electronic Partner. [April 21, 2007].

Bilal, Nihal. Teknolojix. Vice president. [April 17, 2007].

Şernaz, Gamze. Vatan Computer. Marketing and corporate relations management. [April 10, 2007].

Uluşahin, Gamze. Bimeks. Representative of advertising and promotion. [April 10, 2007].

Senem SÖZMEN, Soylu ve Cengiz Danıșmanlık (Teknosa). [10 April 2007]. 